\title{
Improved Physical Fitness Induced by Physiotherapist-led Exercise in Patients With Permanent Atrial Fibrillation Disappears and Health- related Quality of Life Is Impaired After Detraining - A 3 Months Follow-up
}

\section{Research}

Keywords:

Posted Date: December 31st, 2020

DOI: https://doi.org/10.21203/rs.3.rs-136127/v2

License: (c) (i) This work is licensed under a Creative Commons Attribution 4.0 International License. Read Full License 


\section{Abstract}

The authors have requested that this preprint be withdrawn due to erroneous posting.

\section{Full Text}

The authors have withdrawn this preprint from Research Square. 